Amare Tesfie Birhan

Bahir Dar Institute of Technology,

Bahir Dar University, Ethiopia

Mulugeta Teka

Humanities Faculty, Bahir Dar University, Ethiopia

Nibret Asrade

Humanities Faculty, Bahir Dar University, Ethiopia
(iD)

https://orcid.org/0000-0002-8764-8592

\title{
Effects of Using Corpus-Based Instructional Mediation on EFL Students' Academic Writing Skills Improvement
}

\begin{abstract}
This study aimed at examining the effects of corpus-based instructional mediation on EFL learners' academic writing skills improvement. To conduct the research, a quasi-experimental research design was employed. A total of 72 EFL mechanical engineering students participated in the study, and they were selected through a simple random sampling technique. Among them, 25 students were assigned to the experimental group and 47 students to the control group. The data were gathered by means of pre- and post-tests. Multivariate Analysis of Variance (MANOVA) was used to observe the statistical differences between the control and the experimental groups in their academic writing skills. The results showed that the students who were instructed through corpus-based instructional mediation outperformed than the students who were instructed in the conventional instructional approach. Particularly, the students who participated in the experimental group improved their content, communicative achievement, organization, grammar, and vocabulary usage than the students who participated in the control group. Therefore, this research calls for inclusion of corpus-based authentic linguistic elements in their teaching material when teaching academic writing courses in the EFL context.
\end{abstract}

Keywords: academic writing, corpus linguistics, mediation, usage-based 


\section{Introduction}

Information technology has played a significant role in language teaching, learning, and student engagement (Pareja-Lora, Rodriguez-Arancon, \& Calle-Martinez, 2016). Technology facilitates students' autonomous and collaborative language learning. Learners acquire authentic linguistic elements via computer technology: they can read different materials on the computer, get a huge amount of data, revise grammatical and spelling mistakes, compute and compare the frequency of words and translate written texts (Birhan, 2019; Hyland, 2003; Lee, Warschauer, \& Lee, 2017). Hence technology facilitates all phases of academic writing process: planning, drafting, and revising. These factors help learners solve lexical or grammatical problems and generate ideas for writing (Luo, 2016).

The introduction of corpus linguistics, which is the collection of written or spoken texts usually stored in a computer database, is also considered the other contribution of technology (Fuster \& Clavel, 2010). Students, language teachers, and researchers use authentic language data (Braun, 2005) through user-friendly software such as Antconc, Wmatrix, WordSmith tools, and online corpora searching engines like Corpus.BYU.EDU, CQP WEB, etc. Vyatkina and Boulton (2017) confirmed that the corpus started its influence in language teaching and learning as soon as it emerged in the modern form in the 1960s. The corpus data have been used in language classrooms to facilitate the students' second and foreign language acquisition. Since then, the corpus has brought fundamental changes in the second language approach, materials development, curriculum design, and teaching methodology (Cotos, 2014).

Therefore, the use of corpus linguistics as a mediation tool has been realized and discussed by various researchers (e.g., Belz \& Vyatkina, 2008; Meunier, 2011; Perez-Paredes, 2010; Yoon, 2008). The researchers confirmed that corpus linguistics is a viable meditation tool to enhance the students' vocabulary (Szudarski, 2018); writing (Donesch-Jezo, 2010), grammar (Conrad, 2000), and speaking skills (Carter \& McCarthy, 1995; Hilliard, 2014). Language teachers integrate the language teaching with authentic, reliable, and pedagogically relevant contents to satisfy the language learning needs and to fill their learners' language gap.

According to Vygotsky's socio-cultural learning theory, the students' learning can be mediated by their peers, by teachers, and by instructional material or technology (Nieto, 2007). Likewise, corpus informed instruction mediates the students' language learning in two ways: directly and indirectly (Braun, 2005; O'Keeffe, McCarthy \& Carter, 2007).

In a direct approach, teachers/researchers can design learners' corpora or use the existing corpora directly while the students construct academic text 
through an online concordancing program. The direct approach assists learners in identifying the pragmatic function and meaning of words in context (Thurstun \& Candlin, 1998). Vyatkina (2013) suggests that the teacher should support the learners before they start to use the corpus data because it might be difficult to utilize. Brown (2007, p. 308) also mentioned that "many of the widely accessible corpora were created as tools for linguistic research and not with pedagogical goals in mind." Therefore, if the teacher uses the existing corpus data, he/she should guide and direct the students learning.

A second approach is an indirect approach, in which, according to Vyatkina (2013), the teacher prepares corpus-based teaching materials, activities, worksheets for instruction purposes. This approach is one of the favored approaches especially when there are constraints such as the level and experience of learners, time constraints, curricular requirements, knowledge, and skills required for corpus analysis and pedagogical mediation (McEnery \& Xiao, 2011). This approach offers different language samples that increase students' language exposure (Flowerdew, 2009; Szudarski, 2018).

Recently, there are various well-designed corpus-based dictionaries, teaching materials (e.g., Touchstone by McCarthy, McCarten \& Sandiford, 2014), activities, and worksheets that mediate the learners' language skills including writing. Hence, these activities mediate students' language learning in general and academic writing in particular by offering authentic linguistic contents that are frequently used in students' communicative situations. These corpus informed materials indicate the pragmatic function of lexes and guide students while they compose different academic texts. Corpus-based instruction mediates learners to become more aware of text production in a context of use.

\section{Academic Writing and Corpus-based Instructional Mediation}

Academic writing is a demanded skill for higher education students. The students' achievement depends on the quality of project reports, proposals, and assignments they produce. Hence, to produce effective academic writing in fruitful way, the students need to have adequate knowledge of linguistic used by certain academic communities (Coxhead \& Demecheleer, 2018; Ward, 2009).

In academic literacy, researchers (e.g., Chen, 2017; Hardy \& Romer, 2013) stated that there are rhetorical and linguistic element differences among disciplines as well as academic writing genres. Thus, in order to communicate effectively, writers need to know the rhetorical and linguistic structures commonly used in their communicative context. In academic writing, literacy is viewed as beyond copying words and sentences structures; it investigates understanding disciplinary conventions and enables learners to develop a critical view of the 
context of the conventions used (Wingate, 2012). The writers show their positions, arguments, and stances. While learners have real language skills, they can have effective academic writing communication in their discipline (Maher \& Milligan, 2019). The students need to know the academic writing conventions that are used in their disciplines.

Academic writing encompasses various skills. According to Jordan (1997), academic writing involves skills such as organizing ideas appropriately, using cohesive devices, describing, defining, comparing, logical thinking, constructing arguments, finding and analyzing evidence, using data appropriately, etc. Accordingly, to make use of these academic writing skills, the writers' genuine lexical knowledge is crucial.

The students' lexical knowledge is fundamental to language production (Allan, 2016). Particularly, knowledge of lexical bundles and metadiscourses are considered crucial for academic writing improvement and a significant indicator for academic writing ability. Metadiscourse and lexical bundles facilitate communication (Schmitt \& Carter, 2004), social interaction (Jalali \& Moini, 2014), communicative competence (Hyland, 2012), and second language academic literacy acquisition (Shin, Cortes, \& Yoo, 2018). Thus, corpus analysis helps to indicate the genuine metadiscourse and lexical bundles that are frequently used in students' academic and social-communicative context.

Currently, various researchers use corpus linguistics mediation to address the students' language skills gap; the corpus creates an opportunity to overcome the students' academic writing skills challenge. For instance, Reynolds (2015) mediated the EFL students' academic writing gap through the corpus tool and reported that the corpus tool "String Net Navigator" assists students in correcting their academic writing errors. Yoon (2008) also reported corpus mediation to enhance the learners' academic writing confidence. O'Sullivan (2010) also confirmed that corpus consultation enhances students' citations in academic writing. Corpus is vital to present a more genuine and achievable targeted linguistic elements for students' academic writing (Nesi, 2014). It also offers a real-life language use that enables learners to apply authentic language in their communicative situation (Klimova, 2014).

In this way, through corpus analysis, researchers and teachers analyze genuine linguistic elements that satisfy the students' academic writing needs. According to usage-based learning theory, the linguistic structure and meaning are shaped by a specific communicative context (Tyler, 2010).

However, researchers observed that EFL/ESL students encounter challenges due to a lack of authentic lexical knowledge that is crucial to develop effective academic text production. Paquot (2010) observed that 50\% of the students encountered difficulties in using appropriate academic style, expressing ideas in correct English, and linking sentences smoothly. Learners are unable to convey what they want to say properly (Luo, 2016). The students face an enormous 
challenge in using academic writing skills in different contexts (Chang \& Kuo, 2011; O'Sullivan, 2010). These researchers added that students often find it difficult to grasp concepts like argument, thesis statement, and topic sentence and lose their stances which are essential for producing a good academic text and participating actively in the international academic discourse community. These might be because of the lack of formal training in academic writing or the existing practice of teaching writing (Cortes, 2011).

Studies explored that EFL students rarely utilize lexical bundles and metadiscourse linguistic elements that help them compose coherent paragraphs and essays. According to researchers (e.g., Jalali \& Moini, 2014; Wright, 2019), non-native writers rarely used lexical bundles in their academic writing. They are not familiar with the repeated sequence of words (Kazemi, Katiraei, \& Rasekh, 2014). Grabowski (2015) also reported that little attention is paid to lexis in classroom instruction. According to Qiong (2017), one of the features of communicative language teaching is the indebted to the use of authentic texts. In contrast, the lack of pragmatic authenticity of teaching material has been a major problem in the English language classroom (Zahra \& Abbas, 2018) Researchers explicated that lexical grammar or lexical accuracy is a major challenge for EFL/ESL students (see Ferris \& Hedgcock, 1998). According to Maher and Milligan (2019), engineering students do not pay due attention to improving the linguistic knowledge which could help them to produce effective academic writing. Similarly, Ward (2009) indicated that engineering students have little lexical knowledge. This might be partly due to the fact that students do not have sufficient exposure to authentic lexes in their secondary school learning. Likewise, Birhan, Belaye, and Alemahyehu (2020) revealed that at Bahir Dar Institute of Technology, mechanical engineering students use course material that does not include adequate lexical bundles and metadiscourse.

Though researchers like Hyland (2000) reported there are disciplinary cultures that indicate how the rhetorical structure is used in certain disciplines, the way students use lexical bundles and metadiscourse differs from that in use by experts (Cortes, 2004; Hyland, 2008; Kawase, 2015). Therefore, this research was aimed at examining the effects of corpus-based instructional mediation on students' academic writing skills.

Recently, numerous researchers (e.g., Chen \& Flowerdew, 2018; Jalilifar, Mehrabi, \& Mousavinia, 2014; Poole, 2016; Yoon, 2008) studied the impact of corpus instruction on students' language learning. However, these researchers focused on the direct application of corpus linguistics, and their studies are limited in terms of scope and data collection methods.

Besides, various researchers recommended further research to examine the effects of corpus-based instruction in the EFL context. For instance, Mukherjee (2006) asserted that there is a gap between what corpus linguistic offers and what teachers can do (do not do) with corpora in classroom practice. Poole 
(2016) and Yoon and Hirvela, (2004) also recommended further research to provide evidence on the application of corpus work in academic writing skills classes. Hence, this research was conducted considering the recommendation of the above studies to examine the effects of corpus-based mediation on improving EFL students' academic writing skills.

This research hypothesized that students having learnt linguistic, discursive, and pragmatic features on technical report writing through corpus-based instructional mediation would improve their academic writing skills better than students taught the same course in a traditional way. This research was intended to answer the following research questions.

Does corpus-based instructional mediation improve the students' academic writing skills significantly better than the conventional instruction does?

If so, in which component(s) of the students' academic writing is a significant improvement observed?

\section{Method}

\section{Research Design}

The purpose of this research was to examine the effects of corpus-based instructional mediation on improving EFL students' academic writing skills. To observe the effect of the instructional mediation, this research followed a quasiexperimental research design. The research adopted a nonequivalent pre- and post-test control group design.

\section{Participants}

The participants of the study were 72 mechanical engineering students of Bahir Dar Institute of Technology, at Bahir Dar University (Ethiopia). In the 2019/2020 academic year, in the mechanical engineering department, there were five sections of Year IV. Among these, two sections were randomly selected for this study; one of which was assigned as a control group (47 students), and another (25 students) was assigned in an experimental group. In Ethiopia, the English language is taught to students starting from Grade 1 and it is used as a medium of instruction in secondary and tertiary levels. Engineering students take three different English language courses: Communicative English, Basic Writing, and Technical Report Writing and Research Method. 
Being fourth year students, the study participants were taking the course Technical Report Writing and Research Method. The objective of the course is to help engineering and technology students learn the principles of technical writing such as formats, contents grammatical techniques, general procedures of report writing. It is also aimed to improve the essential knowledge of vocabularies and terminologies in science and engineering.

\section{Data Gathering Tools}

The data was gathered via an academic writing test. The academic writing test is one of the common instruments which are used by researchers (e.g Rashtchi \& Ali Mohammadi, 2017; Crossley, Roscoe, \& McNamara, 2014) to assess and observe the students' academic writing improvement as a result of pedagogical intervention. Hence, the students' academic writing tests included gap filling, text revision, data interpretation, and an argumentative text. The tests covered the major research genres such as abstract, introduction, result, and discussion genres.

Thus, except for the gap-filling test, text revision, data interpretation, and the argumentative essay were marked through rubrics/traits by two English language teaching instructors drawing on the Common European Framework of Reference for language-B2 level academic writing assessment scale. The scale contains four components each accompanied by five-point scale descriptors. These components helped to assess the content, meaning, and linguistics (lexical bundles and metadiscourse) of the students' texts. The scale yielded aggregate scores on each component of academic writing skills: content, communicative achievement, organization, and grammar and vocabulary control (Council of Europe, 2001). The validity of the tests was reviewed by two PhD instructors who have been teaching English language courses for more than 20 years. To check the agreement between the two instructors who marked the argumentative essay, Pearson's correlations (Pearson's $r$ ) was applied to estimate the interrater reliability and the obtained coefficient $(r=.80)$ confirmed that it was reliable.

\section{Corpus Design and Intervention}

There are various corpus informed teaching materials. Among these, the Touchstone series by McCarthy, McCarten, and Sandford (2014) and the Cambridge Grammar of English by Carter and McCarthy (2016) are the well-known corpus informed materials. However, they did not address the specific academic writing needs of mechanical engineering students. As Braun (2005, p. 51) contends, "The genuine materials in corpora which have been collected in accordance with pedagogical considerations do seem to create some problems of authentication." 
Therefore, in this study, the researchers considered self-designed small corpora for classroom intervention. Corpus informed studies confirmed that small corpora are more appropriate than general corpora for classroom instruction and specific genre language analysis (Szudarski, 2018). Besides, researchers such as Flowerdew (2009) and Tribble (2001) proved that using small corpora is effective for classroom instruction. Nelson (2010) also asserts "small corpora can offer a balanced and representative picture of a specific area of the language" (p. 55). Small corpora are appropriate for classroom instruction to address the student's specific English language needs.

Hence, the authors of this paper have designed small size corpora from articles published in journals with high impact factor and indexed in Thomson Reuters and Scopus. Considering the journals scope, content coverage, publication language and representativeness to the field, the authors have selected the following eight journals: Advances in Mechanical Engineering, Mechanism and Machine Theory, Mechanical Systems and Signal Processing, International Journal of Mechanical Sciences, Archive of Mechanical Engineering, Journal of Mechanical Engineering, Periodica Polytechnica Mechanical Engineering, and Chinese Journal of Mechanical Engineering. From these journals, 120 (15 articles in each journal) articles were selected. The number of words in each sub-corpus seems to be the following.

Table 1.

$A$ list of articles and number of tokens

\begin{tabular}{llrc}
\hline No. & Journals & Word tokens & Word types \\
\hline 1 & Advances in Mechanical Engineering & 118,387 & 5,259 \\
2 & Mechanism and Machine Theory & 46,455 & 4,706 \\
3 & Mechanical Systems and Signal Processing & 92,218 & 5,955 \\
4 & International Journal of Mechanical Sciences & 96,649 & 6,128 \\
5 & Archive of Mechanical Engineering & 53,015 & 4,523 \\
6 & Journal of Mechanical Engineering & 54,793 & 5,423 \\
7 & Periodica Polytechnica Mechanical Engineering & 47,683 & 5,114 \\
8 & Chinese Journal of Mechanical Engineering & 54,412 & 4,022 \\
Total & & 563,612 & 41,130 \\
\hline
\end{tabular}

While the articles were selected, the researchers used information in the journal's website such as most downloaded, read, and cited articles. AntConc corpus analysis software was also employed to clean and analyze the frequency of metadiscourse and lexical bundles in the selected articles. Manual analysis was also employed to specify the specific function of the selected linguistic element. The metadiscourse and lexical bundles were selected based on the taxonomies of Hyland (2005), Biber et al. (1999, 2003, 2004). 
In this research, the corpus-based instruction was approached through a hands-on activities approach (Boulton, 2010; Reppen, 2010). The researchers have designed a series of lessons to teach the sorted pedagogically relevant metadiscourse items and lexical bundles in a communicative language teaching approach. The experimental group was taught the functions of lexical elements and metadiscourse items explicitly in contexts. Additionally, the students were engaged in text revision, data interpretation, and argumentative writing activities both individually and in group. The students were also committed to revising sample paragraphs and essays which were written by former students.

In this way, the experimental group practiced metadiscourse and lexical bundles through writing argumentative essays, data interpretation, and gapfilling activities. The instruction incorporated the conceptual and theoretical aspects of research and project writing reports. Researchers moderate the instruction by guiding students how to use the selected lexical bundles and metadiscourse devices contextually, facilitating their group discussions and giving gap lectures throughout the intervention. Feedbacks were also given in the students' activities and assignments.

However, the control group was taught through the conventional approach in which the theoretical aspects of report and research writing and accompanying activities included in the course material were treated. This group did not have the exposure to the activities based on the selected metadiscourse and lexical bundles. Both groups attended the course for a four-month-long semester.

\section{Data Analysis Procedure}

In this study, the data collected through the tests were analyzed using Oneway Multivariate Analysis of Variance (One-way MANOVA) on the Statistical Package for the Social Sciences (SPSS) for Windows, Version 24.0. As opposed to using a number of separate t-tests that could result in Type II errors and ignore correlations among the components of the dependent variable, the researchers in this study preferred One-way MANOVA to detect both combined and separate differences by making both multivariate and univariate comparisons between the control group and the experimental group in terms of their means on the four components of the dependent variable: content, communicative achievement, organization, and grammar and vocabulary. Before running this test, the researchers conducted exploratory data analysis to check that all the necessary assumptions were met and determine the possibility of applying the inferential statistics, MANOVA. Accordingly, the exploratory data analysis proved that the data did not have any problem of normal distribution, multicollinearity, outliers, and homogeneity variance-covariance matrices. 


\section{Results}

The results obtained by analyzing the data gathered through writing tests are presented below. Comparison of students' academic writing performance before and after the intervention is presented.

\section{Students' Academic Writing}

The first step was to perform the one-way MANOVA to make a quantitative comparison between the control group and experimental one regarding students' academic writing skills and the four components of this dependent variable: content, communicative achievement, organization, and grammar and vocabulary before the intervention. The main objective of running the MANOVA test on the students' pre-intervention writing performance was to make sure that the two randomly selected intact classes were homogeneous (without significant multivariate and univariate differences) in terms of their academic writing skills before they received respective treatments in the experimental group and in the control one.

Thus, Table 2 presents descriptive statistics (the means and the standard deviations for each group of participants on the four sub-scales of academic writing skills) and the multivariate analysis of variance (MANOVA) results.

Table 2.

Pre-intervention comparison of the two groups and Multivariate Analysis result

\begin{tabular}{|c|c|c|c|c|c|c|c|c|c|}
\hline Variable & Group & $\mathrm{N}$ & Mean & S.D. & df & $\mathrm{F}$ & Sig. & $\begin{array}{l}\text { Wilks' } \mathrm{P} \\
\text { Lambda } \eta \\
\Lambda\end{array}$ & $\begin{array}{l}\text { Partial } \\
\eta^{2}\end{array}$ \\
\hline \multirow[t]{2}{*}{ Content } & Control & 47 & 2.10 & .844 & \multirow{8}{*}{4,67} & \multirow{8}{*}{.551} & \multirow{8}{*}{.699} & \multirow{8}{*}{.968} & \multirow{8}{*}{.032} \\
\hline & Experimental & 25 & 2.06 & .506 & & & & & \\
\hline \multirow{2}{*}{$\begin{array}{l}\text { Communication } \\
\text { Achievement }\end{array}$} & Control & 47 & 2.46 & .475 & & & & & \\
\hline & Experimental & 25 & 2.52 & .420 & & & & & \\
\hline \multirow[t]{2}{*}{ Organization } & Control & 47 & 2.46 & .508 & & & & & \\
\hline & Experimental & 25 & 2.54 & .454 & & & & & \\
\hline \multirow{2}{*}{$\begin{array}{l}\text { Language and } \\
\text { Grammar }\end{array}$} & Control & 47 & 2.19 & .655 & & & & & \\
\hline & Experimental & 25 & 2.06 & .506 & & & & & \\
\hline
\end{tabular}

As shown in Table 2, the study entails the pre-intervention comparison between control and experiment on the four components of students' academic writing skills: content, communicative achievement, organization, and grammar 
and vocabulary. The descriptive statistics results indicated that the two sections registered comparable scores on the content of the writings with a mean score of 2.10 in the control group and 2.06 in the experimental one. The standard deviations are .844 and .506 , respectively. Concerning their communicative achievement, the control group scored a relatively lower mean $(\mathrm{M}=2.46$; $\mathrm{SD}=.475)$ than that of the experimental one $(\mathrm{M}=2.52, \mathrm{SD}=.506)$.

Similarly, the difference in their scores on the organization of their writing was marginally small (i.e., with a mean score of 2.46 in control group and 2.54 in experimental). The standard deviations are .508 and .454 respectively. Moreover, the control group was associated with a numerically higher mean score $(\mathrm{M}=2.19 ; \mathrm{SD}=.655)$ of grammar and vocabulary than the experimental $(\mathrm{M}=2.06$; $\mathrm{SD}=.506)$. This indicated that there were slight mathematical differences between the two groups in their pre-intervention academic writing performance.

Based on these results of the descriptive statistics, multivariate tests were checked to examine if statistically significant multivariate differences could occur between the two groups before they were assigned as experimental and control groups. The results of multivariate tests in the above table revealed a non-significant multivariate difference between the two sections, Wilks's $\lambda=0.968, F(4,67)=.559, p=.699, \eta^{2}=.032$. These results indicated that there were no significant differences between the control and the experimental groups in their academic writing skills on a linear combination of content, communicative achievement, organization, and grammar and vocabulary.

As a rule, there is no need to run further tests of univariate analyses of variance (ANOVAs) after the MANOVA result shows a nonsignificant multivariate effect. However, following the above omnibus test, univariate tests were applied just to show clearly that the two sections recorded nonsignificant differences across each component of the dependent variable. The results of the univariate tests are presented in the table below.

Table 3.

Pre-intervention univariate tests results

\begin{tabular}{lllllllll}
\hline Variable & Group & $\mathrm{N}$ & Mean & S.D. & $\mathrm{df}$ & $\mathrm{F}$ & Sig. & $\begin{array}{l}\text { Partial } \\
\eta^{2}\end{array}$ \\
\hline Content & Control & 47 & 2.10 & .844 & 1,70 & .037 & .847 & .001 \\
& Experimental & 25 & 2.06 & .506 & & & & \\
\cline { 2 - 5 } $\begin{array}{l}\text { Communication } \\
\text { Achievement }\end{array}$ & Control & 47 & 2.46 & .475 & 1,70 & .305 & .583 & .004 \\
Organization & Experimental & 25 & 2.52 & .420 & & & & \\
\cline { 2 - 5 } & Control & 47 & 2.46 & .508 & 1,70 & .461 & .499 & .007 \\
Language and & Experimental & 25 & 2.54 & .454 & & & & \\
Grammar & Control & 47 & 2.19 & .655 & 1,70 & .762 & .386 & .011 \\
& Experimental & 25 & 2.06 & .506 & & & & \\
\hline
\end{tabular}


As can be seen in Table 3, none of the results of the univariate analysis of variance confirmed significant difference. Hence, the observed slight mathematical differences between the two groups were not found statistically significant for all the four components of academic writing skills (i.e., content $\left(F(1,95)=0.713, p<0.400, \eta^{2}=0.007\right)$, communicative achievement, $\left(F(1,95)=2.367, p<0.127, \eta^{2}=0.024\right)$, organization $\left(F\left({ }_{1,95}\right)=2.367\right.$, $\left.p<0.127, \eta^{2}=0.024\right)$, and grammar and vocabulary $(F(1,95)=0.352$, $\left.p<0.554, \eta^{2}=0.004\right)$. Thus, the hypothesis that the two groups were homogeneous before the intervention in terms of content, communicative achievement, organization in their writings was retained.

\section{Post-intervention Multivariate Comparisons}

Considering the results of the assumptions made so far, the experimental group and the control group were compared in their post-intervention writing test performance by running the same statistical test, One-way MANOVA. The researchers compared first the multivariate effect of corpus-based writing instruction on the two groups students' academic writing skills (the combined effect) and then its univariate effects on the four components of the academic writing skills: content, communicative achievement, organization, and grammar and vocabulary.

Accordingly, the post-intervention comparison between the experimental group $(n=25)$ and the control group $(n=47)$ as displayed in Table 4 indicates that the former group registered mathematically better results than the latter in all of the four components of academic writing: content, communicative achievement, organization, and grammar and vocabulary.

Table 4.

Post-intervention comparison of the two groups and Multivariate Analysis result

\begin{tabular}{|c|c|c|c|c|c|c|c|c|c|}
\hline Variable & Group & $\mathrm{N}$ & Mean & SD & $d f$ & $\mathrm{~F}$ & Sig. & $\begin{array}{l}\text { Wilks' } \\
\text { Lambda } \\
\wedge\end{array}$ & $\begin{array}{l}\text { Partial } \\
\eta^{2}\end{array}$ \\
\hline \multirow[t]{2}{*}{ Content } & Control & 47 & 2.21 & .519 & \multirow{8}{*}{4,67} & \multirow{8}{*}{49.8} & \multirow{8}{*}{.000} & \multirow{8}{*}{.251} & \multirow{8}{*}{.749} \\
\hline & Experimental & 25 & 3.02 & .567 & & & & & \\
\hline \multirow{2}{*}{$\begin{array}{l}\text { Communication } \\
\text { Achievement }\end{array}$} & Control & 47 & 2.47 & .488 & & & & & \\
\hline & Experimental & 25 & 3.88 & .415 & & & & & \\
\hline \multirow[t]{2}{*}{ Organization } & Control & 47 & 2.57 & .389 & & & & & \\
\hline & Experimental & 25 & 3.22 & .434 & & & & & \\
\hline \multirow{2}{*}{$\begin{array}{l}\text { Language and } \\
\text { Grammar }\end{array}$} & Control & 47 & 2.25 & .641 & & & & & \\
\hline & Experimental & 25 & 3.10 & .540 & & & & & \\
\hline
\end{tabular}


According to the results, the post-intervention content was associated with a mean score of $3.02(\mathrm{SD}=.567)$ in the experimental group and 2.21 $(\mathrm{SD}=.519)$ in the control group. In terms of the post-intervention communicative achievement results, the experimental group $(\mathrm{M}=3.88, \mathrm{SD}=247)$ was again relatively better than the control group $(\mathrm{M}=2.47, \mathrm{SD}=.488)$. Furthermore, concerning the post-intervention organization, the experimental group $\mathrm{M}=3.22, \mathrm{SD}=.434)$ scored rather higher result as compared to the mean score related to the control group $(\mathrm{M}=2.57, \mathrm{SD}=.389)$.

In order to check whether these mathematical disparities of scores between the two groups differed significantly, multivariate and univariate tests were examined by performing One-way MANOVA. Table 4 also presents the multivariate test result. As can be seen in Table 4, the multivariate differences between the experimental and the control groups were found to be significant with Wilks's $\lambda=.251, F(4,67)=4,98, p=.000, \eta^{2}=.749$. These results showed that corpus-based mediation instruction brought about a significant multivariate difference between the experimental group and the control group on students' content, communicative achievement, organization, and grammar and vocabulary when these four components of the variable are considered collectively.

Since the result of the omnibus test (MANOVA) in Table 4 does not show how much each component of the dependent variable was impacted by the independent variable, this omnibus test had to be followed by univariate analyses of variance (Tests of Between-Subjects Effects). The univariate differences across each component of the dependent variable are presented below.

Table 5.

Post-intervention univariate tests results

\begin{tabular}{llllllllll}
\hline Variable & Group & $\mathrm{N}$ & Mean & SD & df & F & Sig. & $\begin{array}{l}\text { Partial } \\
\eta^{2}\end{array}$ \\
\hline Content & Control & 47 & 2.21 & .518 & 1,70 & 37.012 & .000 & .346 \\
& Experimental & 25 & 3.02 & .567 & & & & \\
\cline { 2 - 5 } $\begin{array}{l}\text { Communication } \\
\text { Achievement }\end{array}$ & Control & 47 & 2.47 & .488 & 1,70 & 148.3 & .000 & .679 \\
Organization & Experimental & 25 & 3.88 & .415 & & & & \\
\cline { 2 - 5 } & Control & 47 & 2.57 & .389 & 1,70 & 41.28 & .000 & .371 \\
Language and & Experimental & 25 & 3.22 & .434 & & & & \\
\cline { 2 - 5 } & Control & 47 & 2.25 & .641 & 1,70 & \multirow{2}{*}{31.42} & .000 & .310 \\
& Experimental & 25 & 3.10 & .540 & & & & \\
\hline
\end{tabular}

The results of univariate analyses of variance revealed a significant effect of corpus-based writing instruction on each component of academic writing (the dependent variable). The results, as shown in Table 5, indicate that the use of 
corpus-based writing instruction brought about a multivariate significant difference between the two groups academic writing performance in terms of content, communicative achievement, organization, and grammar and vocabulary, all in all, favoring the experimental group. The impacts of corpus-based writing instruction on each component of academic writing (content, communicative achievement, organization, and grammar and vocabulary in their academic writing) were found to be dissimilar as can be understood from the above table.

With regards to the content of students' academic writing, the univariate difference between the two groups was found to be significant, $F(1.70)=37,012$, $p=.000, \eta^{2}=.346$. Similarly, the univariate difference between the two groups in terms of communication achievement was found significant, $F(1.70)=143,3$, $p=.000, \eta^{2}=.679$. When comparing the effects of corpus-based writing instruction on each component of academic writing, the difference brought to the two groups by students' communicative achievement (67.9\%) was the highest compared to the other three components: organization $\left(\eta^{2}=.371\right)$, grammar and vocabulary $\left(\eta^{2}=.310\right)$ and content $\left(\eta^{2}=.346\right)$. The effect of corpus-based instructional mediation on students' communicative achievement seemed to take the highest share in the multivariate tests, while the effects on the remaining three components ranged between $31 \%$ and $37.1 \%$.

Additionally, the students employed lexical bundles and metadiscourse device effectively in their argumentative and data interpretation texts, which was not observed before the intervention. The following excerpts are taken from the students' writing.

S1: apart from this it increases employment opportunities...

S2: according to the table the energy of households....

S3: In contrast, in primary and secondary educations, the tables shows that

S4: In my view, globalization contributes a lot by introducing new technologies.

... To start with the first reason, ...

Accordingly, the research findings confirmed that the students who participated in corpus-based mediation performed better in the four major components of academic writing than those who learned academic writing via the conventional approach.

\section{Discussion}

The purpose of this research was to investigate the effects of corpus-based instruction on EFL students' academic writing skills. Hence this study confirmed that corpus-based instructional mediation helped students to improve their language skills. Particularly, the findings indicated that the students who 
participated in the experimental group improved their academic writing skills better than those who were taught their academic writing skills by means of the conventional approach. Moreover, the experimental group showed a significantly better improvement in the content, organization, communicative achievement, and grammar and vocabulary usage in their academic writing skills than the control group.

The findings of this study have been aligned with previous study findings. To mention but a few, Luo and Zhou (2017) proved corpus consultation is crucial to enhance students' certain lexical problems. Similarly, Chitez, Rapp, and Kruse (2015) and Ward (2009) found that corpus linguistics instructional mediation helped to improve the students' academic writing skills. Likewise, Belz and Vytakina (2008) came up to a similar finding that corpus linguistics mediation affects students' language use. Huang (2012) also reported that students who received a corpus-based instruction improved their' knowledge of periphrastic causatives.

Researchers such as Kogan, Yaroshevich, and Ni (2018) also reported that a corpus-based instruction improved academic writing skills. Authentic and genuine linguistic elements helped EFL learners to construct effective academic writing. Students' lexical knowledge is crucial to choose appropriate content, to organize their ideas smoothly, to control their use of vocabulary and grammar, and to achieve their communicative goals in their academic writing. More specifically, the finding of this study is consistent with AbdelWahab's (2020) findings in terms of the improved components of students' academic writing skills (content, organization, vocabulary, and language use) and with Asadi's (2018) work in terms of the effect of using metadiscourse devices on students' academic writing skills.

Likewise, this research indicated that mechanical engineering students who were instructed through corpus-based instructional mediation improved their awareness regarding the utilization of lexical bundles and metadiscourse which occurred frequently in their field of studies. According to a usage-based theory, language is confined to a specific context in which it is used, and the user shapes language features (meaning and structure) according to the context. Likewise, the meaning and the structure of a language are determined by identity of the users (Baker, 2006). Thus, the lexical bundles and metadisocurse function vary according to the contexts in which it is used and according to the people who use them. In academic writing, corpus mediates students' language learning by showing the pragmatic functions of a specific linguistic elements which occur frequently in their field of studies. Baybee and Beckner (2010) and Ibbotson (2013) also mention that language is developed with social interaction.

Therefore, teachers can use corpus data to design authentic academic writing teaching materials. Asik (2017) asserts that corpus-informed materials ad- 
dress the students' language learning needs. When teachers prepare teaching materials, they should consider pedagogically relevant contents and motivate students to use them in their communicative situations.

\section{Conclusions}

Corpus-based instructional mediation assists students how to use genuine linguistic elements that occur frequently in their discipline while they construct academic writing texts. This study proved that corpus-based instructional mediation was a viable instructional tool to enhance students' academic writing skills. The research found that students who participated in the experimental group improved their lexical knowledge better than students who learned their academic writing skills through holistic approach. The experimental group improved their content, organization, communicative achievement, and grammar and vocabulary usage skills better than students who were taught through the traditional teaching material and method. The students also employed metadiscourse and lexical bundles effectively and properly in their argumentative essay and data interpretation texts.

The findings of this research have various implications. First, the findings implied that computer technology plays an indispensable role to discover lexical bundles and metadiscourse elements that can be used in students' social context. Second, the finding implied that English language teachers should consider empirical language data to prepare academic writing teaching material, to address students' academic writing needs than relying on teacher made examples and language contents; teachers should depend on authentic examples and linguistic contents.

Moreover, the finding implied that teachers can select specific linguistic elements (for instance lexical bundles and metadiscourse) to enhance their learners' lexical knowledge. Corpus-based instructional mediation could meet the academic writing communicative needs of students. The corpus-based instructional mediation raises the students' awareness on how to use lexical bundles and metadiscourse in different academic genres. 


\section{References}

AbdelWahab, A. (2020). Using interactive and interactional metadiscourse markers to develop EFL first year special diploma students' academic writing skills. Journal of Faculty of Education Assiut University, 36(2), 1-35.

Allan, R. (2016). Lexical bundles in graded readers: To what extent does language restriction affect lexical patterning? System, 59, 61-72.

Asadi, A. (2018). Enhancing writing skills of English learners through metadiscourse resources. MEXTESOL, 42(3), 1-19.

Asik, A. (2017). A sample corpus integration in language teacher education through coursebook evaluation. Journal of Language and Linguistic Studies, 13(2), 728-740.

Baker, P. (2006). Using corpora in discourse analysis. London-New York: Continuum.

Baybee, J., \& Beckner, C. (2010). Usage-Based Theory. Accessed October 11, 2018 Retrieved from: https://www.unm.edu/ jbybee/downloads/BybeeBeckner2010UsageBasedTheory.pdf

Belz, J., \& Vyatkina, N. (2008). The pedagogical mediation of a developmental learner corpus for classroom-based language instruction. Language Learning and Technology, 12(3), 33-52.

Biber D. (2009). A corpus-driven approach to formulaic language in English. International Journal of Corpus Linguistic, 14(3), 275-311.

Biber, D., Johnsson, S., Leech, G., Conrad, S., \& Finegan, E. (1999). Longman grammar of spoken and written English. Harlow: Pearson Education.

Biber, D., Conrad, S. \& Cortes, V. (2003). Towards taxonomy of lexical bundles in speech and writing. In A. Wilson, P. Rayson, \& T. McEnery (Eds.), Corpus linguistics by the Lune: A festschrift for Geoffrey Leech (pp. 71-92). Frankfurt a. Main: Peter Lang.

Biber, D., Conrad, S., \& Cortes, V. (2004). If you look at...: Lexical bundles in university teaching and textbooks. Applied Linguistics, 25(3), 371-405.

Birhan, A. T. (2019). [Review of the book Teaching language and teaching literature in virtual environment by Maria Luisa Carrio-Pastor]. Journal of Language and Education, 5(3), $111-113$.

Birhan, A. Belaye, N. Alemayehu, Y. (2020). Lexical usage by Mechanical discipline writers and the students' academic writing needs (unpublished project). Ethiopia: Bahir Dar University.

Boulton, A. (2010). Data-driven learning: Taking the computer out of the equation. Language Learning, Wiley, 60(3), 534-572.

Braun, S. (2005). From pedagogically relevant corpora to authentic language learning contents. ReCALL, 17(1), 47-64.

Breyer, Y. (2008). Learning and teaching with corpora: Reflections by student teachers. Computer Assisted Learning, 22(2), 153-172.

Brown, S. (2007). Integrating corpus work into secondary education: From data-driven learning to needs-driven corpora. ReCALL, 19(3), 307-328.

Carter, R. \& McCarthy, M. (1995). Grammar and spoken language. Applied Linguistics, 16(2), $141-158$.

Carter, R., \& McCarthy, M. (2016). Cambridge grammar of English: A comprehensive guide spoken and written English grammar and usages. Cambridge: Cambridge University Press.

Chang, C., \& Kuo, C. (2011). A corpus-based approach to online materials development for writing research articles. English for Specific Purposes, 30, 222-234.

Chen, M., \& Flowerdew, J. (2018). Introducing data-driven learning to PhD students for research writing purposes: A territory-wide project in Hong Kong. English for Specific Purposes 50, 97-112. 
Chen, S. (2017). Disciplinary variations in academic promotional writing: The case of statements of purpose. Functional Linguistics, 4(4), 1-14.

Chitez, M., Rapp, C., \& Kruse, O. (2015). Corpus-supported academic writing: How can technology help? In F. Helm, L. Bradley, M. Guarda, \& S. Thouseny (Eds.), Critical CALLProceeding of the 2015 EUROCALL conference, Padova, Italy (pp. 125-132). Dublin: Research-publishing.net.

Conrad, S.M. (2000). Will corpus linguistics revolutionize grammar teaching in the 21 st century? TESOL Quarterly, 34(3), 548-560.

Cortes, V. (2004). Lexical bundles in published and student disciplinary writing: examples from history and biology. English for Specific Purposes, 23, 397-423.

Cortes, V. (2011). Genre analysis in the academic writing class: With or without corpora. Quaderns de Filologia: Estudis Linguistics, 16, 65-80.

Cotos, E. (2014). Enhancing writing pedagogy with learner corpus data. ReCALL 26(2), 202-224.

Coxhead, A., \& Demecheleer, M. (2018). Investigating the technical vocabulary plumbing. English for Specific Purposes, 51, 84-97.

Crossley, S., Roscoe, R., \& McNamara, D. (2014). What is successful writing? An investigation into the multiple ways writers can write successful essays. Written Communication, 31(2), 184-214.

Donesch-Jezo, E. (2010). Corpus concordancing in teaching academic discourse writing to medical students. International Conference in ICT for Language Learning 3rd edition. Retrieved from: https://www.researchgate.net/publication/268378354_Corpus_concordancing in teaching_academic_discourse_writing_to_medical_students

Ferris, D., \& Hedgcock, J. (1998). Teaching ESL composition: Purpose, process and practice. Mahwah, NJ: Lawrence Erlbaum.

Flowerdew, L. (2009). Applying corpus linguistics to pedagogy: A critical evaluation. International Journal of Corpus linguistics, 14(3), 393-417.

Fuster, M., \& Clavel, B. (2010). Corpus linguistics and its applications in higher education. Revista Alicantina de Estudios Inglese, 23, 51-67.

Grabowski, L. (2015). Keywords and lexical bundles within English pharmaceutical discourse: A corpus-driven description. English for Specific Purposes, 38, 23-33.

Hardy, J., \& Romer, U. (2013). Revealing disciplinary variation in student writing: A multidimensional analysis of the Michigan corpus of upper-level student papers (MICUSP), Corpora, 8(2), 183-207.

Hilliard, A. (2014). Spoken grammar and its role in the English language classroom. English Language Teaching Forum, 4, 1-13.

Huang, Z. D. (2012). Can concordance improve the lexico-grammatical use of abstract nouns in L2 writing? Asia Pacific Corpus Linguistics Conference. Auckland: University of Auckland.

Hyland, K. (2000). Disciplinary discourses: Social interactions in academic writing. London: Longman.

Hyland, K. (2003). Second language writing. Cambridge: Cambridge University Press.

Hyland, K. (2005). Metadiscourse: Exploring interaction in writing. London: Continuum.

Hyland, K. (2008). Academic clusters: Text patterning in published and postgraduate writing. International Journal of Applied Linguistics, 18(1), 41-62.

Hyland, K. (2012). Bundles in academic discourse. Annual Review of Applied Linguistics, 32, $150-169$.

Jalali, Z., \& Moini, M. (2014). Structure of lexical bundles in introduction section of medical research articles. Procedia-Social and Behavioral Sciences, 98, 719-726. 
Jalilifar, A., Mehrabi, K., Mousavinia, S., (2014). The effects of concordance enriched instruction on the vocabulary learning and retention of Iranian EFL learners. Procedia-Social and Behavioral Sciences, 98, 742-746.

Jordan, R. R. (1997). English for academic purpose. Cambridge: Cambridge University Press.

Kawase, T. (2015). Metadiscourse in the introductions of PhD theses and research articles. Journal of English for Academic Purposes, 20, 114-124.

Kazemi, M., Katiraei, S., Rasekh, A. E. (2014). The impact of teaching lexical bundles on improving Iranian EFL students' writing. Procedia-Social Behavioral Science, 98, 864-869.

Klimova, B. (2014). Using corpus linguistics in the development of writing. Procedia-Social and Behavioral Sciences, 141, 124-128.

Kogan, M., Yaroshevich, A., \& Ni, O. (2018). Corpus-based teaching of German compound nouns and lexical bundles for improving academic writing skills. Revue de linguistique et de didactique des langues, 58, 1-24.

Lee, H., Warschauer, M., \& Lee, J. H. (2017). The effects of concordance-based electronic glosses on L2 vocabulary learning. Language Learning \&Technology, 21(2), 32-51.

Luo, Q. (2016). The effects of data-driven learning activities on EFL learners' writing development. Spring Plus, 5(1255), 1-23.

Luo, Q., \& Zhou, J. (2017). Data-driven learning in second language writing classes: A survey of empirical studies. International Journal of Emerging Technologies in Learning, 12(3), 182-196.

Maddalena, S. R. (2001). An investigation into how corpus analysis may be used in the second language classroom to solve some of the problems surrounding non-native speakers' understanding of seemingly synonyms words. Accessed May, 6, 2020. Retrieved from: ERIC at https://www.eric.ed.gov/?q=An+Investigation + into + How + Corpus + Analysis + May + Be+Used + in + the + Second + Language + Classroom + To + Solve + Some + of + the + Problems + Surrounding + Non-Native + Speakers $\% 27+$ Understanding + of + Seemingly + Synonymous + Words

Maher, P., \& Millgan, S. (2019). Teaching master thesis writing to engineers: Insights from corpus and genre analysis of introductions. English for Specific Purposes, 55, 40-55.

McCarthy, M., McCarthen, J., \& Sandford, H. (2014). Touchstone: Student's book. Cambridge: Cambridge University Press.

McEnery, T., \& Xiao, R. (2011). What corpora can offer in language teaching and learning? In E. Hinkel (Ed.), Handbook of research in second langue teaching and learning (pp. 364-380). London: Routledge.

Meunier, F. (2011). Corpus linguistics and second/foreign language learning: Exploring multiple paths. RBLA, Belo Horizonte, 11(2), 459-477.

Mukherjee, J. (2006). Corpus linguistics and language pedagogy: The state of the art and beyond. In S. Braun, K. Kohn, \& J. Mukherjee (Eds.), Corpus technology and language pedagogy: New resources, new tools, new methods (pp. 5-24). Frankfurt a. Main: Peter Lang.

Nelson, M. (2010). Building a written corpus: What are the basics? In A. O'Keeffe \& M. McCarthy (Eds.), The Routledge handbook of corpus linguistics (pp. 53-65). Routledge. Taylor and Francis group.

Nesi, H. (2014). Corpora and English for academic purposes. Retrieved from: http://www2. warwick.ac.uk/fac/soc/al/research/collect/bawe/papers/corpora_and_eap.pdf

Nieto, C. (2007). Applications of Vygotskyan concept of mediation in SLA. Colombian Applied Linguistics Journal, 9, 213-228.

O'Keeffe, A., McCarthy, M., \& Carter, R. (2007). From corpus to classroom: Language use and Language teaching. Cambridge: Cambering University Press.

O'Sullivan, I. (2010). Using corpora to enhance learner's academic writing skills in French. Revue Francaise de Linguistique Appliquee, 15(2), 21-35. 
Paquot, M., (2010). Academic vocabulary in learning writing: From extraction to analysis. London: Continuum.

Pareja-Lora, A., Rodriguez-Arancon, P., \& Calle-Martinez, C. (2016). Applying information and communication technologies to language teaching and research. In A. Pareja-Lora, C. Calle-Martinez, \& P. Rodriguez-Arancon (Eds.), New perspectives on teaching and working with languages in the digital era (pp. 1-22). Dublin: Research-Publishing.net.

Perez-Paredes, P. (2010). Corpus linguistics and language education in perspective: Appropriate and the possibilities scenario. In T. Harris \& M. Moreno Jaen (Eds.), Corpus linguistics in language teaching (pp. 53-73). Frankfurt a. Main: Peter Lang.

Poole, R. (2016). A corpus-aided approach for the teaching and learning of rhetoric in an undergraduate composition course for L2 writers. English for specific purpose, 21, 99-109.

Qiong, H. (2007). Corpora and English teaching: Retrospect and prospect. International Journal of Scientific Research and Innovative Technology, 4(7), 65-73.

Rashtchi, M., \& Ali Mohammadi, M. (2014). Teaching lexical bundles to improve academic writing via tasks: Does the type of input matter? Electronic Journal of Foreign Language Teaching, 14(2), 201-219.

Reppen, R. (2010). Using corpora in the language classroom. Cambridge: Cambridge University Press.

Reynolds, B. L. (2015). Action research: Applying a bilingual parallel corpus collocational concordance to Taiwanese medical school EFL academic writing. RELC Journal, 47(2), 213-227.

Schmitt, N., \& Carter, R. (2004). Formulaic sequences in actions: An introduction. In N. Schmitt (Ed.), Formulaic sequences: Acquisition, processing and use (pp. 1-22). Amsterdam, Netherlands: John Benjamins.

Shin, Y. K., Cortes, V., \& Yoo, I. W. (2018). Using lexical bundles as a tool to analyze definite article use in L2 academic writing: An exploratory study. Journal of Second Language Writing, 39, 29-41.

Szudarski, P. (2018). Corpus linguistics for vocabulary: A guide for research. Routledge: Taylor \& Francis group.

Thurstun, J., \& Candlin, C. (1998). Concordancing and the teaching of the vocabulary of academic English. English for Specific Purposes, 17(3), 267-280.

Tribble, C. (2001). Corpora and corpus analysis: New windows on academic writing. In J. Flowerdew (Ed.), Academic discourse. Harlow, UK: Addison Wesley Longman.

Tyler, A. (2010). Usage-based approaches to language and their applications to second language learning. Annual Review of Applied Linguistics, 30, 270-291.

Vyatkina, N. (2013). Discovery learning and teaching with electronic corpora in an advanced German grammar course. Teaching German, 46(1), 44-61.

Vyatkina, N., \& Boulton, A, (2017). Corpora in language learning and teaching. Language Teaching and Technology, 21(3), 1-8.

Ward, J. (2009). A basic engineering English word list for less proficient foundation engineering undergraduates. English for Specific Purposes, 28(3), 170-182. https://doi.org/0.1016/j. esp.2009.04.001

Wingate, U. (2012). Using academic literacies and genre-based models for academic writing instruction: A 'literacy' journey. English for Academic Purposes, 11(1), 26-37. https://doi. org/10.1016/j.jeap.2011.11.006

Wright, H. (2019). Lexical bundles in stand-alone literature reviews: sections, frequencies and functions. English for Specific Purposes, 54, 1-14.

Yoon, H. (2008). More than a linguistic reference: The influence of corpus technology on L2 academic writing. Language Learning and Technology, 12(2), 31-48. 
Yoon, H., \& Hirvela, A. (2004). ESL Student attitudes toward corpus use in L2 writing. Journal of Second Language Writing, 13, 257-283.

Zahra, T., \& Abbas, A. (2018). Pedagogical implications of corpus-based approaches to ELT in Pakistan. Journal of Education and Educational Development, 5(2), 259-275.

Amare Tesfie Birhan, Mulugeta Teka, Nibret Asrade

\section{Der Einfluss von korpusbasierter unterrichtlicher Vermittlung auf die Verbesserung der akademischen Schreibkompetenzen von EFL-Studierenden}

\section{Zusammenfassung}

Das Ziel der vorliegenden Studie ist es, den Einfluss von korpusbasierter unterrichtlicher Vermittlung auf die Verbesserung der akademischen Schreibkompetenzen von EFLStudierenden zu untersuchen. Zur Durchführung der Untersuchung wurde ein quasi-experimentelles Forschungsmodell verwendet. Insgesamt nahmen 72 EFL-Maschinenbaustudierenden daran teil, die durch eine einfache Zufallsstichprobe ausgewählt wurden. 25 Studierende wurden der Experimentalgruppe und 47 Studierende der Kontrollgruppe zugeordnet. Die Daten wurden mit Hilfe von Vor- und Nachtests erhoben. Dabei wurde die Multivariate Varianzanalyse (MANOVA) verwendet, um die statistischen Unterschiede zwischen der Kontroll- und Experimentalgruppe in Bezug auf ihre akademischen Schreibkompetenzen zu untersuchen. Die Ergebnisse zeigten, dass die Studierenden, die durch korpusbasierte unterrichtliche Vermittlung unterrichtet wurden, bessere Leistungen erbrachten als die Studierenden, die man mit dem konventionellen unterrichtlichen Ansatz unterrichtete. Im Vergleich zu den Teilnehmern der Kontrollgruppe verbesserten die Teilnehmer der Experimentalgruppe insbesondere den Inhalt, kommunikative Leistungen, die Organisation, Grammatik und den Wortschatzgebrauch. Daher postuliert die Studie die Einbeziehung von korpusbasierten, authentischen sprachlichen Elementen in das Lehrmaterial der akademischen Schreibkurse im EFL-Kontext.

Schlüsselwörter: akademisches Schreiben, Korpuslinguistik, Vermittlung, gebrauchsbasiert 
